\title{
EXAMPLES OF HISTORICAL UNDERGROUND MINING SITES IN NORTHERN HUNGARY (TELKIBÁNYA, SALGÓTARJÁN)
}

\author{
Wojciech KACZAN \\ Doctoral candidate, Wrocław University of Science and Technology, \\ Faculty of Geoengineering, Mining and Geology
}

Salgótarján, Telkibánya,

Hungary, geotourism, underground routes

\begin{abstract}
Nowadays, there are no operating deep-cast mines in Hungary, the last one - Úrkút manganese mine was closed in 2016. The purpose of this article is to briefly present two historical underground mines and theirs recent condition. First of them is Telkibánya - a gold mine placed in Tokaj Mountains. Second one is a brown coal mine in Salgótarján. Field works were focused on the most significant and accessible remainings in those regions - Mária adit in Telkibánya and Joseph adit in Salgótarján.
\end{abstract}

\section{Telkibánya}

Telkibánya is situated in the north part of the Tokaj Mountains. The west border of the structure is related with the Hernad fault, north-east border with the Szamos fault and the south-east border with a Bodrog fault. The Tokaj Mountains are mostly built of neogenic (Sarmatian) volcanic rocks like: andesites, dacites, rhydacites, rhyolites, rhyolite tuffs (Society, 2009).

The deposit within Telkibánya area is a typical low sulphidation type epithermal gold-silver deposit with shallow erosion level $(200-500 \mathrm{~m})$. The temperature of the deposit formation is estimated to $180-260{ }^{\circ} \mathrm{C}$ from the predominantly boiling hydrothermal solutions with low salinities. The hydrothermal circulation was driven by a subvolcanic intrusion emplaced in the middle of a caldera-like structure. Concentration of gold occurred due to boiling and asso- 
ciated with that gas loss and mixing of high temperature parent fluids with steam-heated fluids (Molnár et al., 2009).

Mining in Telkibánya has a long history and it is troublesome to describe it in detail as there are only few written documents available. The first known document of Telkibánya is dated back to 1270 , where the King István V mentioned the name. In 1341, the King Károly I declared Telkibánya as a royal mining camp. In the 14th century due to a long period of development, Hungary became one of the most important gold and silver supplier for Europe. The town's importance is highlighted by a sentence "Telkibánya with a golden button" which was used to describe the site back then (Benke, 2009).

From 1442 to 1470 town was occupied by Husits. They had destroyed majority of the buildings, but left the mine in operation, because of the benefits coming from it. In the late 15 th century mining towns in Hungary were organized in the Association of the Upper Hungarian Mining Towns. It helped to develop and overcome issues like external threat, higher demand of capitalisation and more complicated exploitation conditions. The association has lasted only until the beginning of the 16th century (Benke, 2009).

During those times mines were struggling with many technological problems like dewatering and transportation. These issues were solved thanks to use of water energy and Thurzó-Fugger cooperation. János Thurzó was a businessman with exceptional technical instinct who implemented numerous innovations in mining process. Jakob Fugger was a rich banker from Augsburg, so he provided money for investments. They created a company called Ungarischer Handel. Its main goal was to buy mines in many European countries and improve their performance (Benke, 2009). It shall be noticed that they also ran some projects in Reichenstein (now - Złoty Stok, Poland) (Dziekoński, 1972).

Many events of the city are described in Protocollum - book kept by the local protestant priests. One fragment of the book is particulary interesting. In 1443 miners found precious ore. They started enthusiastic exploitation. The mining officer noticed signals of mine fall, but miners did not listen to him. The fall has killed 360 people. Later it was concluded, that the reason of the fall was an earthquake, and the real number of fatalities was around 120. After the catastrophe the mining activities were suspended. Moreover, in the end of 16th century hard times for Hungarian mines has begun. It was related to the lack of rich ore, wars and technological issues, but simultaneously the economic impact of America's discovery was observed in the whole Europe (Benke, 2009).

The last golden age occurred when Maria Theresa (1740-1780) from the Habsburg dinasty ruled the country. She ordered reopening of the Telkibánya mines (Molnar et al., 2010). The ore field was surveyed and the result of it was a map with the artistic level (Benke, 2009). Mária and Teréz adits described in this article were named after the empress Maria Theresa. In 1788 the mine be- 
came a state enterprise and the underground activities were undertaken (Molnár et al., 2010).

During next centuries exploitation in Telkibánya has been started and stopped few times. In 1951 the exploration had been undertaken by the Ministry of Mining and Energy, but 9 years later it was concluded that mining in this area was not profitable anymore (Benke, 2009).

Nowadays, the underground parts of Telkibánya mine are closed. Only Mária Adit is available for education purposes. Initially, the plan was to transform it into a tourist attraction but there were few obstacles. First of all - difficulties with access, because the road is the national army property and the entrance to adit is hidden in woods. Secondly, before the reopening in 2007 two entrances to the adit were buried. Recently, only one is available and reinforced. The last obstacle is that the underground route is too short and with too small touristic potential. It is mostly interesting for specialists, scientists or mining and geology students (information from F. Mádai).

The preparation and reopening of the Mária Adit was undertaken in the course of Hungary-Slovakia Cross-border Co-operation Programme 2007-2013. Moreover, the adit was documented in detail and the assessment of environmental impact of the old mining activities was made (information from F. Mádai).

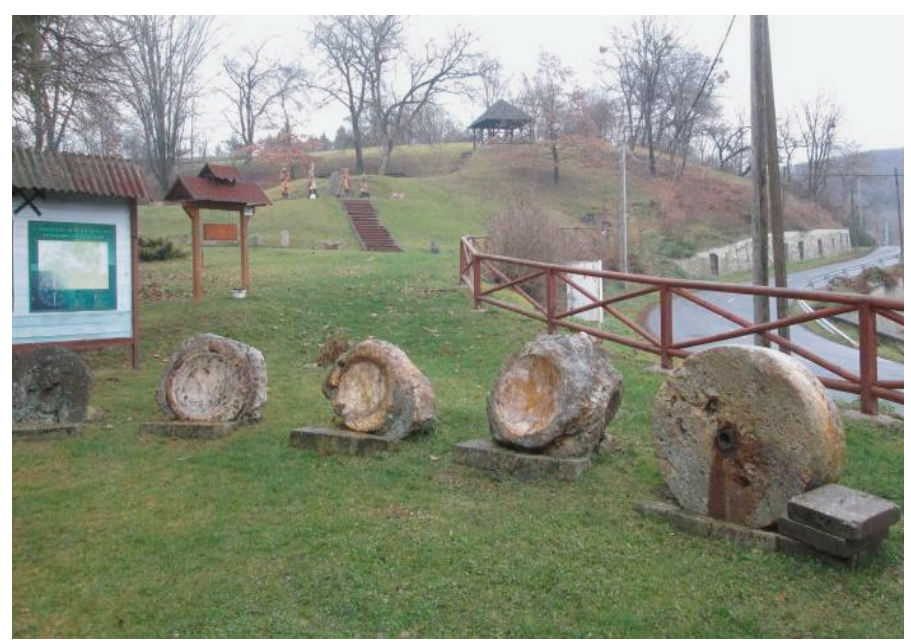

Fig. 1. Stone mills in front of the Museum of Ore and Mineral Mining in Telkibánya Ryc. 1. Kamienne młyny przed Muzeum Wydobycia Rud i Minerałów w Telkibánya

As it was mentioned before, the terrain of Telkibánya contains many mining relicts. Shafts, adits, open-cast mining pits and ruins of surface facilities can be found in numerous places. The potential of this spot was noticed and it resulted in a 9-kilometer long touristic path through its most important parts. The route 
leads to Veres-víz Valley - an old enrichment plant, Fehér Hill Quarry - where white rhyolites are exposed, Lipót Shaft - a ventilation shaft from XV century, Teréz and Csengö - inaccessible adits, and at the end of the route many small scale open-pits are located (Society, 2017).

The Museum of Ore and Mineral Mining in Telkibánya is located in the heart of the city. Its exhibitions are focused on minerals and rocks from different sites in Hungary and the history of the industry. For instance, in the museum can be found: models of dewatering systems in a mine and old equipment like stone mills, hammers or lamps (Fig. 1).

\section{Mária adit}

The entrance to the Mária adit is located on the west slope of Kánya Hill in the heart of the Telkibanya ore field, at the height of $517 \mathrm{~m}$ a.s.l. and is facing east. The explored part of the adit is around 250 meters long. This underground part was driven in andesites which were altered by K-metasomatic processes. Concentrating of gold and silver had place in nearly vertical veins. Mária adit cuts through three of them: Lobkowitz, Jó Szerencsét and Jupiter (Fig. 2).

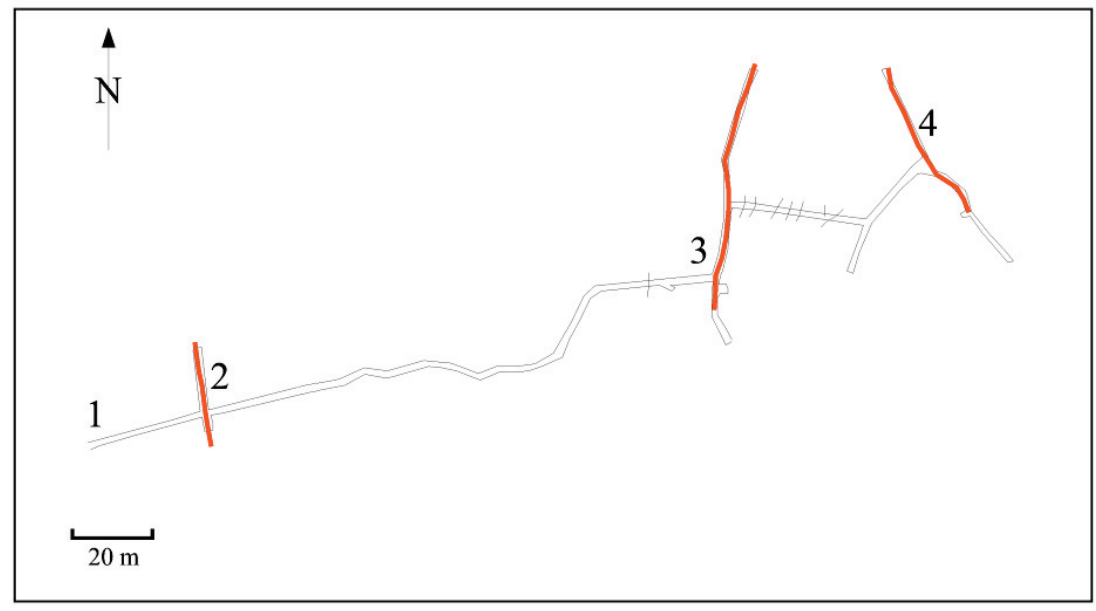

Fig. 2. Plan of the Mária Adit; 1 - entrance to the adit, 2 - Lobkowitz vein, 3 - Jó Szerencsét vein, 4 - Jupiter vein (plan received from dr Ferenc Mádai)

Ryc. 2. Plan sztolni Mária; 1 - wlot sztolni, 2 - żyła Lobkowitz, 3 - żyła Jó Szerencsét, 4 - żyła Jupiter (plan otrzymany od dr Ferenca Mádai)

The entrance to the adit is wooden, resembling the one in Teréz Adit (Fig. 3). Next part, around 20 meters long, was enforced with brick lining. It is the only 
place in Mária adit, where rockmass casing is used. Right after this fragment the first gold vein appears - Lobkowitz. It has north-south strike and $10-20 \mathrm{~cm}$ in thickness. This structure forms a boundary between $2-3 \mathrm{~m}$ thick brecciation zone and a zone of fragmented host rock, which disappears within $5 \mathrm{~m}$ distance from the structure to the west. The structure of this vein is composed of coarseto medium-grained tectonic breccia, which is cemented by light-to-dark brown clay and ochre (Sasvári \& Kondela, 2009).

The adit west towards the Jó Szerencsét vein (Eng. Good luck). On the walls and roof many alteration zones are visible. Those places are infilled by limonite and goethite, which are the results of oxidation of andesites. When the adit reaches the Jó Szerencsét vein, the ramification leads to the south and the north. The south directed tunnel is inaccessible after a blind shaft which is driven few meters from the ramification. North directed one leads forward to further parts of the mine (to Jupiter vein), but author stopped there because of his safety (Fig. 2).

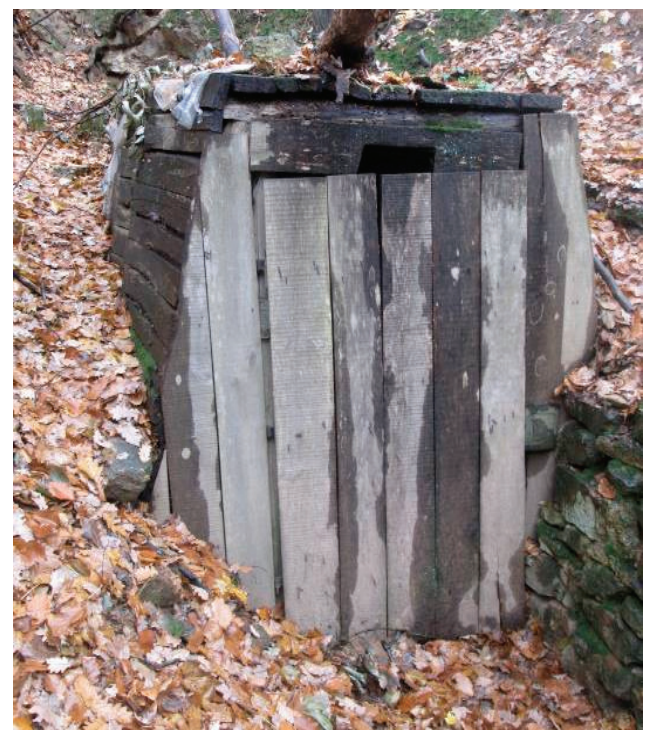

Fig. 3. Wooden entrance to Mária Adit, November 2017 Ryc. 3. Drewniany obudowa wloty sztolni Mária, listopad 2017

The Jó Szerencsét vein is characterised by the widest alteration zone, intense alteration and very variable composition of vein material. It has $0.3-1.2 \mathrm{~m}$ in thickness, strike equal 30 degrees, and it dips to the south-east. This vein has symmetrical alteration pattern, unlike Lobkowitz vein. The centre consist of a volcanic breccia zone altered into clay, whereas the breccia content associated with the clasts of different sizes, increases toward the edges of the vein (Sasvári \& Kondela, 2009). 


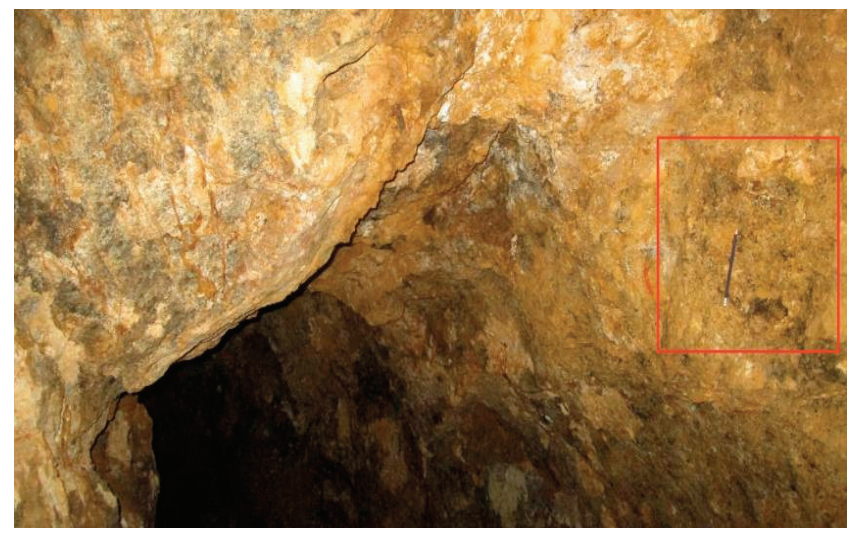

Fig. 4. Jó Szerencsét vein; visible oxidation zones on the rockmass; red marking - the gouge where a platform was assembled Ryc. 4. Żyła Jó Szerencsét; widoczne strefy utlenione;

czerwone oznaczenie - wyżłobienie, w którym montowana była platforma

Above the ramification is a blind shaft, which was excavated because of the high concentration of ore in this fragment of Jó Szerencsét vein. The roof is supported with a steel mesh to protect from failin stoens. The walls are carved because miners used special platform to reach upper parts of the rich section of the deposit (Fig. 4).

\section{Salgótarján}

The word "Salgótarján" is built of two words from ancient Hungarian: Salgó - shine and tarján - the name of Hungarian tribe. Salgótarján existed in Middle Ages, but then it was just a small village (www.salgótarján..., 2018).

The beginning of the mining is dated 1848 , when first private firms started to operate there. Due to their activity, rapid development of this small city took place. It has influenced on the society structure which previously was mainly built of farmers. (Horváth and Csüllög, 2012). In 1922 Salgótarján officially became the mining town (Osobliwości..., 2007).

After World War II Hungary changed its system to socialism. Industry was nationalised. In the 1950s Salgótarján was a real socialist town. In 1952 Nógrád Coal Mining Trust was founded. It caused great increase in production of coal, simultaneously in open-cast and underground mines. In the 1960s and 1970s the old town was almost fully demolished to be replaced by a new town centre of prefabricated buildings and tower blocks. After 1970 the situation on industry started to worsen. Underground and even open-cast mining was not profitable anymore. Due to fall of industry, unemployment has risen from $0 \%$ in 1980 to $12.8 \%$ in 2007 (Horváth 
\& Csüllög, 2012). Nowadays, no mining operations are being undertaken in this region. Only Joseph adit is opened as a touristic attraction.

It is important to mention that terrain of Salgótarján is a part of NovohradNógrád Geopark which occupies $1.587 \mathrm{~km}^{2}$ of transborder territory and comprises the administrative area of 63 settlements in Hungary and 28 habitations in Slovakia (www.europeangeoparks..., 2018). Novohrad - Nógrád Geopark was admitted as official member of Global Geopark Networks in 2010, with assistance of European Geoparks Network, which is under the authority of UNESCO. This Geopark is the first transboundary Geopark in the whole world (www.nogradgeopark..., 2018; www.slovakia..., 2018).

The terrain of Novohrad-Nógrád Geopark is dominated by hills, valleys and basins. Due to intense geological history of this area, the landscapes are varied. Rolling hills, volcanic plateaus and lowlands over-shadowed by volcanic peaks are present there. The peaks were ideal for fortresses in the middle ages, and hidden valleys were perfect for a growth of unique communities. This makes terrain of Novohrad-Nógrád Geopark even more valuable (www.globalgeopark..., 2018).

\section{Joseph adit}

Joseph adit is the first Underground Mining Museum in Hungary (Osobliwości..., 2017), and the second one in the whole Europe. Mining activities in this place has stopped in 1951. During next years this site was used as an exercise facility for mine rescuers. The underground mining museum was opened in 1965. The creation of such a place was considered as a good way to show almost 100 years old history of Salgótarján mining (Szvirscek, 2018).

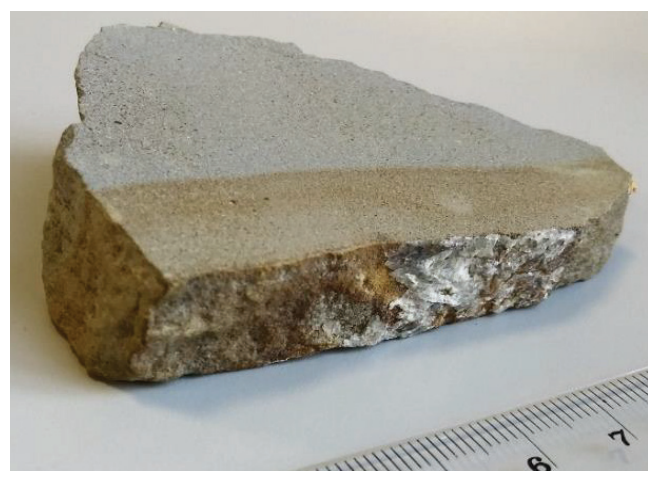

Fig. 5. Rock sample from Joseph adit; grey and yellow sandstone with calcite occurrence Ryc. 5. Próbka skalna pobrana w sztolni Joseph; szary oraz żółty piaskowiec $\mathrm{z}$ wystąpieniem kalcytu 
The touristic route is 280 meters long, and shows chronologically the history of mining from XIX and XX century. It is drifted in overburden layer which consists mostly of sandstone. Taken rock sample represents fine-grained, grey and yellow sandstone. On the sample's surface there is visible transition between these two colours. On the sample's edge occur calcite minerals - reaction with the hydrochloric acid was observed (Kaczan, 2018; Fig. 5).

The touristic route is full of different exhibitions to show the most important aspects of underground mining activities. Every tunnel in the museum is supported by various linings and support, for example the circular lining (Fig. 6 - point 2), the wooden lining (Fig. 6 - point 4) or longwall roof support (Fig. 6 -9). The stable reminds of an underground work of horses (Fig. 6 - point 3 ), but on the way there is also shown hard work of miners in harsh conditions - hand work in drifts with low roof (Fig. 6 -4). To present water management system which is a big part of underground mining, tourists can see sump with the pump chamber and electronic pump (Fig. 6-6).

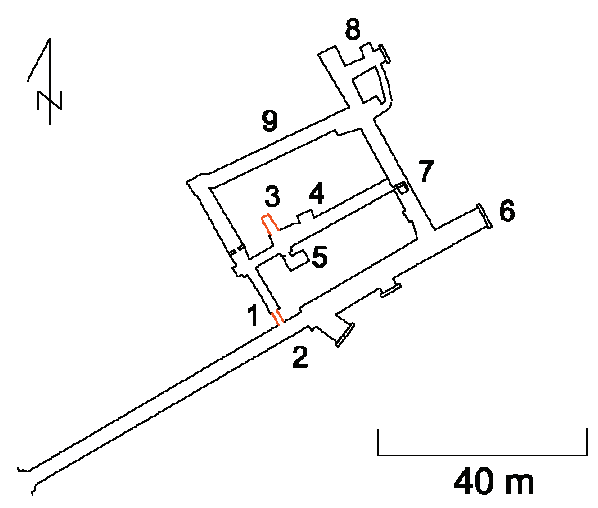

Fig. 6. Plan of Joseph Adit; red colour - uncovered rockmass;

1 - location of rock sampling , 2 - circular lining, 3 - stable, 4 - exhibition of the work in harsh conditions, 5 - exercise room for rescuers, 6 - sump, 7 - ventilation shaft,

8 - exhibition of work in room-and-pillar system, 9 - exhibition of work in longwall method (based on documents received in the museum)

Ryc. 6. Plan sztolni Joseph; czerwonym kolorem oznaczono zauważone fragmenty odsłoniętego górotworu; 1 - miejsce opróbowania, 2 - obudowa kołowa podatna, 3 - stajnia, 4 - ekspozycja pracy w ciężkich warunkach, 5 - komora ćwiczeniowa dla ratowników, 6 - rząpie,

7 - szyb wentylacyjny, 8 - ekspozycja systemu komorowo-filarowego,

9 - ekspozycja systemu ścianowego (na podstawie materiałów uzyskanych w muzeum)

Next really important aspect of the underground mining is the ventilation. This was presented with the use of fans, pipes and the ventilation shaft (Fig. 6 -7). The mining systems in Nógrád Basin has changed throughout the years. 
Until 1960 in the coal basin were used room and pillar mining (Fig. 6 - point 8) and the short faced breastwork - Nógrád-type work (Szvircsek, 2018). Modernisation led to use of longwall mining system. During the tour systems are presented and described (Fig. 6 - point 9). Moreover there is possibility to see and hear still working polish-made longwall shearer KWB-3D.

In front of the adit's entrance there is a place with exhibited numerous, different mining machines, and a building which is the outside museum.

\section{Summary}

Recently, in Hungary there are no operating underground mines. The last one Úrkút manganese mine was closed in 2016. Mária adit and Joseph adit are the remainders that this branch of industry had place in Hungary in past days.

First of them is a site that is available for students and specialists. Its richness cannot be provided for wider audience because it is not officially a touristic route. Hungary-Slovakia project (2007-2013) gave a chance to prepare this site for education purposes. The geology of the deposit in this area is an interesting topic and was deeply investigated.

Joseph adit was opened as a museum years ago. It is not a huge facility but exhibitions are well prepared and thought out. They show all aspects of coal mining. From the ventilation, lining, mining systems to even withdrawal and different historical workings (horses, hand-work).

\section{Acknowledgements}

I thank to dr Ferenc Madai from University of Miskolc for providing the possibility to visit Telkibánya mining site and for comments to this article. I am grateful to Peter Prakfalvi for the help and guide in Salgótarján.

\section{Literature}

BENKE T., 2009. The history of the mining of Telkibánya. Geosciences - Telkibánya Geology. Miskolc Univ. Press, Series A, Mining, 78: 7-25.

HORVÁTH G., CSÜLlÖG G., 2012. Salgótarján (Hungary) - The Rise and Fall of a Mining and Industrial Region. [In]: Wirth P., Černič Mali B., Fischer W. Post-mining regions in Central Europe. Problems, Potentials, Possibilities. Oekom Verl. München.

HORVÁTH G., CSÜLLÖG G., 2013. A new Slovakian-hungarian cross-border geopark in central Europe - possibility for promoting better connections between the two countries. European Countryside 5, 2: 146-162.

KACZAN W., 2018. Porównanie charakteru budowy geologicznej wybranych podziemnych tras turystycznych $w$ dawnych wyrobiskach górniczych i określenie dostępności górotworu dla przygotowanie specjalistycznej oferty geoturystycznej [Comparison of the geological struc- 
ture of selected underground tourist routes in former mining excavations and determination of the availability of rock mass for the preparation of specialistic geotouristic offer] (master thesis - unpublished). Archive of Wrocław Univ. of Science and Technol. (in Polish).

MOLNÁR F., NAGRYMAROSY A., JELEŇ S., BAČO P., 2010. Minerals and wines: Tokaj Mts., Hungary and Slanské vrchy Mts., Slovakia. [In:] Acta Mineralogica-Petrographica, Field Guide Series, 15: 1-40.

MOLNÁR F., ZELENKA T., PÉCSKAY Z., 2009. Geology, styles of mineralization and spatialtemporal characteristics of the hydrothermal system in the low-sulphidation type epithermal gold-silver deposit at Telkibánya. Miskolc Univ. Press, Series A, Mining, 78: 45-70.

OSOBLIWOŚCI kraju Paloców, 2007. [In:] Naturalnie... poszukiwanie przygód w Pótnocnych Węrzech. Węgierska Turystyka S.A. Reg. Dyr. Marketing. Północnych Węgier Komárom.

SASVÁRI I., KONDELA J., 2009. Structural characteristics of epithermal, low-sulphide precious metals mineralization at Telkibánya, Tokaj Mountains, Hungary. Miskolc Univ. Press, Series A, Mining, 78: 115-139.

SOCIETY of Economic Geologists Student Chapter University of Miskolc, 2018. Sampling methods on active and abandoned mining areas. Field trip raport. Industrial minerals in the NE part of Hungary. Acces on: https://www.segweb.org/pdf/students/student-chapters/university-of-miskolc/ Field-Trip-Report-2.pdf.

SZVIRCSEK F., The Mining Exhibition Facility of The Nógrád Historical Museum. The Salgótarján Mining Museum. Webpage of Mining Museum in Salgótarján http: //banyamuzeum salgotarjan.lapunk.hu/?modul=oldalandtartalom=1081900\#angol (access: December 2018).

www.europeangeoparks.org/?page id $=548$ - EUROPEANgeoparks, Webpage of European Geoparks Network (access: December 2018).

www.globalgeopark.org/aboutGGN/list/HungarySlovakia/6438.htm - Webpage of Global Geopark Network (access: December 2018).

www.nogradgeopark.eu/en/organisation - NOGRADgeopark, Official webpage of Nograd Geopark (access: December, 2018).

www.salgótarján.hu - Webpage of Salgótarján city (access: December 2018).

www.slovakia.travel/en/novohrad-geopark - Official webpage for information and promoting Slovakia tourism (access: December, 2018).

\title{
PRZYKŁADY DAWNYCH OBIEKTÓW GÓRNICZYCH PÓŁNOCNYCH WĘGIER (TELKIBÁNYA, SALGÓTARJÁN)
}

\author{
Telkibánya, Salgótarján, Hungary, \\ dawne górnictwo, geoturystyka
}

Obecnie na Węgrzech nie ma żadnej działającej kopalni podziemnej. Ostatnia kopalnia Úrkút została zamknięta w roku 2016. Przykładami dawnego górnictwa podziemnego tego kraju jest kopalnia złota i srebra Telkibánya oraz kopalnia węgla brunatnego Salgótarján. Leżą one w północnej części Węgier. Niniejszy komunikat jest wynikiem robót terenowych przeprowadzonych $\mathrm{w}$ tych lokalizacjach z naciskiem na dostępne sztolnie - Mária, leżąca w Telkibánya, oraz Joseph - leżąca w Salgótarján. Pierwsza z wymienionych nie jest udostępniona turystom, a jedynie użytkowana okresowo przez studentów wydziałów geologicznych i górniczych. Druga z nich została zagospodarowana jako muzeum już w roku 1965. Sztolnia Mária to przykład obiektu o dużych walorach naukowych, jednak stosunkowo mniejszym potencjale geoturystycznym. $\mathrm{Z}$ pewnością na uwagę zasługuje długa historia wydobycia bardzo cennego kruszca oraz aspekty geologiczne. Sztolnia Joseph mimo swoich niewielkich rozmiarów, ale za to długiej historii istnienia jako muzeum ukazuje wszelkie aspekty związane z górnictwem podziemnym węgla. 